\title{
Responses of Phospholipase D and Antioxidant System to Mechanical Wounding in Postharvest Banana Fruits
}

\author{
Li Li, ${ }^{1,2}$ Xuemei He, ${ }^{1}$ Jian Sun, ${ }^{1,2}$ Changbao Li, ${ }^{1,2}$ Dongning Ling, \\ Jinfeng Sheng, ${ }^{1,2}$ Fengjin Zheng, ${ }^{1}$ Guoming Liu, ${ }^{1}$ Jiemin Li, ${ }^{1,2}$ Yayuan Tang, \\ Ping Yi, ${ }^{1}$ Ming Xin, ${ }^{1}$ Zhichun Li, ${ }^{1}$ and Zhugui Zhou ${ }^{1}$ \\ ${ }^{1}$ Agro-Food Science and Technology Research Institute, Guangxi Academy of Agricultural Sciences, 174 East Daxue Road, \\ Nanning 530007, China \\ ${ }^{2}$ Guangxi Key Laboratory of Fruits and Vegetables Storage-Processing Technology, 174 East Daxue Road, Nanning 530007, China
}

Correspondence should be addressed to Jian Sun; jiansun@gxaas.net

Received 10 June 2017; Accepted 17 September 2017; Published 19 October 2017

Academic Editor: Shifeng Cao

Copyright (C) $2017 \mathrm{Li} \mathrm{Li} \mathrm{et} \mathrm{al.} \mathrm{This} \mathrm{is} \mathrm{an} \mathrm{open} \mathrm{access} \mathrm{article} \mathrm{distributed} \mathrm{under} \mathrm{the} \mathrm{Creative} \mathrm{Commons} \mathrm{Attribution} \mathrm{License,} \mathrm{which}$ permits unrestricted use, distribution, and reproduction in any medium, provided the original work is properly cited.

\begin{abstract}
Banana fruits are susceptible to mechanical damage. The present study was to investigate the responses of phospholipase D (PLD) and antioxidant system to mechanical wounding in postharvest banana fruits. During $16 \mathrm{~d}$ storage at $25^{\circ} \mathrm{C}$ and $90 \%$ relative humidity, PLD activity in wounded fruits was significantly higher than that in control (without artificial wounding fruits). The higher value of PLD mRNA was found in wounded fruits than in control. PLD mRNA expression reached the highest peak on day 4 in both groups, but it was 2.67 times in wounded fruits compared to control at that time, indicating that PLD gene expression was activated in response to wounding stress. In response to wounding stress, the higher lipoxygenase (LOX) activity was observed and malondialdehyde (MDA) production was accelerated. The activities of antioxidant enzymes such as superoxide dismutase (SOD), catalase (CAT), peroxidase (POD), and ascorbate peroxidase (APX) in wounded fruits were significantly higher than those in control. The concentrations of reactive oxygen species (ROS) such as superoxide anion $\left(\mathrm{O}_{2}{ }^{--}\right)$and hydrogen peroxide $\left(\mathrm{H}_{2} \mathrm{O}_{2}\right)$ in fruits increased under mechanical wounding. The above results provided a basis for further investigating the mechanism of postharvest banana fruits adapting to environmental stress.
\end{abstract}

\section{Introduction}

Mechanical damage is the main cause for losses in postharvest horticultural products $[1,2]$. Wounds represent vulnerable points that may lead to severe damage and compromise organ survival rate. Membrane deterioration is an early and characteristic feature in plant cells undergoing mechanical injuries [3]. Membrane integrity loss is often associated with lipid peroxidation or phospholipid degradation. The increased lipid peroxidation, mediated and sustained by phospholipiddegrading enzymes such as phospholipase D (PLD) and lipoxygenase (LOX), results in membrane integrity loss, which has been noted in senescing petal tissues [4]. PLD and LOX in plants play important roles in phospholipid catabolism, initiating lipolytic cascade in membrane deterioration during senescence and stress $[5,6]$. LOX, encoding a lipoxygenase involved in jasmonate (wounding-induced signaling molecule) synthesis, is transcriptionally upregulated in response to wounding in Arabidopsis [7]. It has been proposed that the liberated polyunsaturated fatty acids serve as substrates for LOX that produces activated oxygen and lipid peroxides leading to membrane damage [8]. PLD has been proposed to play several roles in wounding response. The increased PLD-mediated hydrolysis occurs in response to various stress conditions such as frost, senescence, and wounding [9]. Plants accumulate phosphatidic acid (PA) and unesterified fatty acids that are released from lipids, presumably by the action of wound-inducible phospholipases of types D after wounding $[7,10]$. The wounding-induced activation of PLD may result from translocation of PLD to the membrane, which is mediated by an increase in cytoplasmic calcium and stimulated by low micromolar calcium levels 
$[11,12]$. In castor bean leaves, it has been reported that free fatty acid quantity and PLD activity increase with wounding. Increases in membrane-associated PLD and LOX have been observed in response to mechanical wounding in postharvest cucumber fruits [8].

A wound signal originates at injury site and propagates into adjacent tissue where it induces a number of physiological responses, including lipid degradation, peroxidation compound synthesis and accumulation, and subsequent tissue browning [13]. The oxylipin pathway is involved in wound responses in a number of plants. Antioxidant enzymes are critical in inhibiting oxidative stress. When reactive oxygen species (ROS) increases, chain reactions start in which superoxide dismutase (SOD) catalyzes the dismutation of superoxide radical $\left(\mathrm{O}_{2}{ }^{--}\right)$to molecular oxygen $\left(\mathrm{O}_{2}\right)$ and hydrogen peroxide $\left(\mathrm{H}_{2} \mathrm{O}_{2}\right) \cdot \mathrm{H}_{2} \mathrm{O}_{2}$ is then detoxified by catalase (CAT), peroxidase (POD), and ascorbate peroxidase (APX) [14]. CAT reduces $\mathrm{H}_{2} \mathrm{O}_{2}$ into water and $\mathrm{O}_{2}$, whereas POD decomposes $\mathrm{H}_{2} \mathrm{O}_{2}$ by oxidation of cosubstrate such as phenolic compounds [15].

Banana (Musa acuminate L.) is one of the major commercial fruit crops grown in tropics and subtropics. It is very important to the economy of developing countries [16]. Banana fruits are very susceptible to mechanical damage during harvesting, handling, packaging, and transportation, which results in a substantial reduction in quality. Mechanical wounding significantly reduces the commercial value of banana fruits [17]. Lipid degradation and peroxidation activities are directly involved in natural and induced senescence and mechanical wounding. With regard to harvested banana fruits, it is important to discern potential roles of lipid degradation and antioxidant enzymes in association with mechanical wounding. The aim of this research was to explore the role of PLD, LOX, and oxidative stress in banana fruits subjected to artificial wounding and senescence processes. Molecular characterization of PLD in response to wounds and senescence was also analyzed. These innovative results will provide a scientific basis for further investigating the mechanism of postharvest banana adapting to environmental stress.

\section{Materials and Methods}

2.1. Plant Materials and Postharvest Treatments. Banana fruits were collected from a commercial orchard in Nanning of Guangxi province during July 2016 and transported into a laboratory in Guangxi Academy of Agricultural Sciences immediately. The fruits without infection and physical injury were chosen as plant materials at similar size and same mature period. They were randomly divided into wounded and control groups (100 fruits in each group). In wounded group, banana fruits were punctured at $3 \mathrm{~cm}$ intervals from the calyx to the stalk end by a $10 \mathrm{~mm}$ diameter stainless steel puncher. The fruits which were not punctured were used as control group. Both groups were packed into polyethylene bag $\left(0.03 \mathrm{~mm}\right.$ thick) and stored at $25^{\circ} \mathrm{C}$ and $90 \%$ relative humidity $(\mathrm{RH})$. Every 6 fruits were taken for the determination every $2 \mathrm{~d}$ after wounding.
2.2. PLD Activity. PLD activity was assayed by means of highly specific and sensitive sandwich enzyme immunoassay technique (ELISA) [18]. The 96-well ELISA plates (Nunc, Wiesbaden, Germany) were coated with the purified plant PLD antibody $(100 \mu \mathrm{L}$ per well, $2 \mathrm{mg} / \mathrm{mL}$ diluted $1: 1000$ in PBS, $\left.4^{\circ} \mathrm{C}, 8 \mathrm{~h}, \mathrm{pH} 7.2-7.4\right)$. Plates were then blocked with $1 \%$ BSA in PBS for $16 \mathrm{~h}$ at $37^{\circ} \mathrm{C}$. The wells were then washed twice with $200 \mu \mathrm{L}$ of wash buffer. A series of PLD standards were prepared in range 10-120 U/L in PBS/0.1\% BSA. Samples were also prepared in a series of dilutions from $1 / 5$ to $1 / 50$ in PBS. A total of $50 \mu \mathrm{L}$ of standards and samples were added and incubated for $2 \mathrm{~h}$ at $37^{\circ} \mathrm{C}$. The wells were then washed twice with $100 \mu \mathrm{L}$ of wash buffer. Conjugate binding was performed by adding a biotin-conjugated antibody specific for PLD ( $100 \mu \mathrm{L}$ of $0.1 \%$ conjugate antibody in $0.1 \%$ BSA/PBS). After being incubated for $60 \mathrm{~min}$ at $37^{\circ} \mathrm{C}$, the plates were washed three times with wash buffer and three times with $100 \mu \mathrm{L}$ of carbonate buffer. Horseradish Peroxidase (HRP) $(100 \mu \mathrm{L}$ of $15 \mathrm{mg}$ HRP in $15 \mathrm{~mL}$ of carbonate buffer) was added and incubated for $10 \mathrm{~min}$ at $37^{\circ} \mathrm{C}$. The absorbance of the plates was then read at $450 \mathrm{~nm}$ on an ultraviolet (UV) microplate reader (Bio-Rad Laboratories, Hercules, California, USA).

2.3. Semiquantitative RT-PCR Analysis. Total RNAs were extracted from $3 \mathrm{~g}$ of fresh banana pericarp tissues using CTAB method [19]. Total RNA samples were then dissolved in $50 \mu \mathrm{L}$ of RNase free $\mathrm{H}_{2} \mathrm{O}$ and stored at $80^{\circ} \mathrm{C}$ prior to RTPCR. Total RNA ( $5 \mu \mathrm{g}$ ) was used for the cDNA synthesis with the Reverse Transcription System A3500 (Promega, Madison, WI, USA) according to the protocol provided by the manufacturer. The fragment of PLD cDNA was cloned by RT-PCR. PCR was carried out with an initial heat action step at $94^{\circ} \mathrm{C}$ for $6 \mathrm{~min}$, and amplifications were achieved through 35 cycles at $94^{\circ} \mathrm{C}$ for $30 \mathrm{~s}, 53^{\circ} \mathrm{C}$ for $30 \mathrm{~s}$, and $72^{\circ} \mathrm{C}$ for $90 \mathrm{~s}$. A final extension reaction was carried out for $6 \mathrm{~min}$ at $72^{\circ} \mathrm{C}$. The resulting PCR product was isolated, cloned, and sequenced (Invitrogen, Shanghai, China).

The mRNA expression patterns of PLD gene were examined by semiquantitative RT-PCR. The house-keeping gene Actin (GenBank accession number AB046952) was used as an internal control. Protocols for total RNA extraction and synthesis of cDNA were described as above. Gene specific primers for PLD (PLD-S3: 5'-GAAATCGGGAGGTCAAGAAGAG-3'; PLD-A3: $5^{\prime}$-CTAAGTTGTGAGGATTGGAGG-3 $3^{\prime}$ ) and Actin (forward: $5^{\prime}$-GATTCTGGTGATGGTGTGAGT-3' ; reverse: $5^{\prime}$-GACAATTTCCCTTAGCAG-3') were used in RT-PCR. PCR was carried out with an initial heat action step at $94^{\circ} \mathrm{C}$ for $5 \mathrm{~min}$, and amplifications were achieved through 35 cycles at $94^{\circ} \mathrm{C}$ for $30 \mathrm{~s}, 55^{\circ} \mathrm{C}$ for $30 \mathrm{~s}$, and $72^{\circ} \mathrm{C}$ for $1 \mathrm{~min}$, with a final extension at $72^{\circ} \mathrm{C}$ for $10 \mathrm{~min}$. The amplified products $(10 \mu \mathrm{L})$ were analyzed by $1 \%$ agarose gel electrophoresis [19].

2.4. LOX Activity. The frozen banana pericarp tissues (5 g) were ground finely in liquid nitrogen and then homogenized in $15 \mathrm{~mL}$ of $50 \mathrm{mM}$ phosphate buffer ( $\mathrm{pH} \mathrm{7}$ ). After centrifugation at $10,000 \times \mathrm{g}$ for $20 \mathrm{~min}$ at $4^{\circ} \mathrm{C}$, the supernatant was collected and then used as crude enzyme extract. LOX 
activity was assayed by monitoring the formation of conjugated dienes from linoleic acid at $25^{\circ} \mathrm{C}$ and $234 \mathrm{~nm}$ [20]. A total of $3 \mathrm{~mL}$ of reaction mixture contained $50 \mathrm{mM}$ sodium phosphate buffer $(2.8 \mathrm{~mL}, \mathrm{pH} 7), 10 \mathrm{mM}$ sodium linoleic acid solution $(0.1 \mathrm{~mL})$, and crude enzyme solution $(0.1 \mathrm{~mL})$. One unit of LOX activity was defined as a change of 0.01 in absorbance per minute at $25^{\circ} \mathrm{C}$.

2.5. Activities of Antioxidative Enzymes. CAT and POD were extracted and assayed according to the modified methods of Oracz et al. [21]. Banana pericarp tissues $(0.5 \mathrm{~g})$ were extracted for $10 \mathrm{~min}$ with $2.5 \mathrm{~mL}$ of $0.1 \mathrm{M}$ sodium phosphate buffer $(\mathrm{pH} 7)$ at $4^{\circ} \mathrm{C}$. The extract solution was centrifuged for $15 \mathrm{~min}$ at $12,000 \times \mathrm{g}$. The supernatant was collected as enzyme solution for the determinations of enzymatic activities. The assay mixture $(3 \mathrm{~mL})$ for determining CAT activity consisted of $2.8 \mathrm{~mL}$ of $15 \mathrm{mM} \mathrm{H} \mathrm{H}_{2} \mathrm{O}_{2}$ prepared by $0.05 \mathrm{M}$ sodium phosphate buffer ( $\mathrm{pH} 7.8$ ) and $0.2 \mathrm{~mL}$ of enzyme solution. The increase in absorbance at $240 \mathrm{~nm}$ was recorded for $3 \mathrm{~min}$ at $25^{\circ} \mathrm{C}$. The assay mixture $(3 \mathrm{~mL})$ for determining POD activity consisted of $2.5 \mathrm{~mL}$ of $0.1 \mathrm{M}$ sodium phosphate buffer $(\mathrm{pH}$ 7), $0.2 \mathrm{~mL}$ of $0.46 \%(\mathrm{v} / \mathrm{v}) \mathrm{H}_{2} \mathrm{O}_{2}, 0.2 \mathrm{~mL}$ of $4 \%(\mathrm{v} / \mathrm{v})$ guaiacol, and $0.1 \mathrm{~mL}$ of enzyme solution. The increase in absorbance at $470 \mathrm{~nm}$ was recorded for $3 \mathrm{~min}$ at $25^{\circ} \mathrm{C}$.

SOD was extracted and assayed according to the modified methods of Sun et al. [22]. Banana pulp tissues (0.5 g) were extracted for $10 \mathrm{~min}$ at $4^{\circ} \mathrm{C}$ with $2.5 \mathrm{~mL}$ of $0.05 \mathrm{M}$ sodium phosphate buffer ( $\mathrm{pH} 7.8$ ) containing $0.1 \%(\mathrm{w} / \mathrm{v})$ polyvinyl pyrrolidone. The extract solution was centrifuged for $20 \mathrm{~min}$ at $12,000 \times \mathrm{g}$. The supernatant was collected for analyzing SOD activity. SOD activity was determined by measuring its ability to inhibit the photochemical reduction of nitro blue tetrazolium (NBT). A total of $0.05 \mathrm{~mL}$ of enzyme solution was added to $3 \mathrm{~mL}$ of assay reagent consisting of $13 \mathrm{mM}$ methionine, $63 \mu \mathrm{M}$ NBT, $100 \mu \mathrm{M}$ EDTA, and $1.3 \mu \mathrm{M}$ riboflavin in $0.05 \mathrm{M}$ sodium phosphate buffer ( $\mathrm{pH} 7.8)$. The reaction solutions were incubated for 10 min under 4,000 lux illumination. The absorbance of sample was measured at $560 \mathrm{~nm}$ and $0.05 \mathrm{M}$ sodium phosphate buffer ( $\mathrm{pH} 7.8$ ) was used as control.

The assay for APX activity was determined according to the modified method of Nakano and Asada [23]. APX activity consisted of $0.1 \mathrm{mM}$ EDTA- $\mathrm{Na}_{2}, 0.5 \mathrm{mM}$ ascorbic acid, and $0.1 \mathrm{mM} \mathrm{H}_{2} \mathrm{O}_{2}$ (above-mentioned reagents were prepared in $0.05 \mathrm{M}$ sodium phosphate buffer, $\mathrm{pH}$ 7) and $0.1 \mathrm{~mL}$ of enzyme solution. The activity was recorded as the decrease in absorbance at $290 \mathrm{~nm}$. One enzyme unit was defined as $1 \mathrm{~mol}$ of ascorbic acid oxidized per minute at $290 \mathrm{~nm}$.

2.6. MDA Content. Malondialdehyde (MDA) content was measured according to the reported method of Sun et al. with a slight modification. Banana pulp tissues ( $3 \mathrm{~g}$ ) were homogenized with $15 \mathrm{~mL}$ of $10 \%$ trichloroacetic acid and centrifuged at $15,000 \times \mathrm{g}$ for $20 \mathrm{~min}$ [22]. One milliliter of supernatant was mixed with $3 \mathrm{~mL}$ of $0.5 \%$ 2-thiobarbituric acid, heated at $95^{\circ} \mathrm{C}$ for $20 \mathrm{~min}$, and then immediately cooled in an ice-water bath. The absorbance was measured at $532 \mathrm{~nm}$ after centrifugation at $3,000 \times \mathrm{g}$ for $10 \mathrm{~min}$ and the value for nonspecific absorbance $600 \mathrm{~nm}$ was subtracted. The amount of MDA was estimated as follows: $(\mu \mathrm{M} / \mathrm{g} \mathrm{FW})=[6.45$ $\left.\left(\mathrm{OD}_{532}-\mathrm{OD}_{600}\right)-0.56 \mathrm{OD}_{450}\right] \times 5 \mathrm{~mL} / 0.25 \mathrm{~g}$.

2.7. Superoxide Anion Content. Superoxide radical $\left(\mathrm{O}_{2}{ }^{--}\right)$ was determined by the conversion of nitro blue tetrazolium (NBT) staining according to Dunand et al. [24]. The banana powder (1g) was vacuum-infiltrated with $10 \mathrm{mM} \mathrm{NaN}_{3}$ in $10 \mathrm{mM}$ potassium phosphate buffer ( $\mathrm{pH} 7.8$ ) for $1 \mathrm{~min}$ and incubated in $1 \mathrm{mg} / \mathrm{mL}$ NBT (in $10 \mathrm{mM}$ potassium phosphate buffer, $\mathrm{pH}$ 7.8) for $20 \mathrm{~min}$ in the dark at room temperature.

2.8. $\mathrm{H}_{2} \mathrm{O}_{2}$ Content. $\mathrm{H}_{2} \mathrm{O}_{2}$ levels were determined according to the modified method of Velikova et al. [25]. The banana powder $(0.5 \mathrm{~g})$ was homogenized for $10 \mathrm{~min}$ in $2.5 \mathrm{~mL}$ of cold acetone. The homogenate was centrifuged for $15 \mathrm{~min}$ at $12,000 \times \mathrm{g}$. A total of $1 \mathrm{~mL}$ of supernatant was added to $0.1 \mathrm{~mL}$ of $20 \%(\mathrm{v} / \mathrm{v})$ titanium tetrachloride $\left(\mathrm{TiCl}_{4}\right)$ and $0.2 \mathrm{~mL}$ of ammonia water. After centrifuging for $15 \mathrm{~min}$ at $12,000 \times \mathrm{g}$, the precipitate was collected and dissolved in $3 \mathrm{~mL}$ of $1 \mathrm{M}$ $\mathrm{H}_{2} \mathrm{SO}_{4}$ and centrifuged for $5 \mathrm{~min}$ at $6,000 \times \mathrm{g}$. The absorbance of the supernatant was measured at $412 \mathrm{~nm}$. The content of $\mathrm{H}_{2} \mathrm{O}_{2}$ was calculated from a standard curve. The increasing rate of $\mathrm{H}_{2} \mathrm{O}_{2}$ content $(\%)=\left[\left(C_{i}-C_{0}\right) / C_{0}\right] \times 100$, where $C_{i}$ indicated $\mathrm{H}_{2} \mathrm{O}_{2}$ content in banana fruits storing for different times, while $\mathrm{C}_{0}$ was $\mathrm{H}_{2} \mathrm{O}_{2}$ content in banana fruits storing for $0 \mathrm{~d}$.

2.9. Statistical Analysis. Experiments were arranged in a completely randomized design. All statistical analyses were performed by variance (ANOVA) analysis using Statistix version 8.0 (Analytical Software, Tallahassee, FL, USA). Treatment means were compared by Fisher's Least Significant Difference (LSD) test at a significance level of $P<0.05$.

\section{Results}

3.1. Phospholipase D Activation and PLD Gene Expression in Postharvest Banana Fruits under Mechanical Wounding. PLD activity was correlated with mechanical wounding. From Figure 1, at $25^{\circ} \mathrm{C}$ and $90 \% \mathrm{RH}$, banana PLD activity demonstrated a rapid increase tendency in both control and wounded fruits with extended storage time and attained maximum on day 2 and day 4, respectively. PLD activity in wounded fruits was significantly higher $(P<0.05)$ than that in control throughout the entire storage period. After day 4, PLD activity increased 2-fold in wounded fruits while increasing only 1.6-fold in control. The accumulation of banana PLD mRNA in response to mechanical wounding was further investigated (Figure 2). Similar to PLD activity profile, PLD expression was found to be upregulated with the extended storage and reached the highest expression peak on day 4 in control (1.48 times the control on day 0 ) and then decreased on day 6. In wounded fruits, PLD expression also attained a maximum on day 4 (3.14 times to control on day 0 ). The higher value (3.95) of PLD mRNA was found in wounded fruits than that in control, and PLD mRNA expression in wounded fruits was 2.67 times that in control on day 4 , indicating that PLD gene expression was 


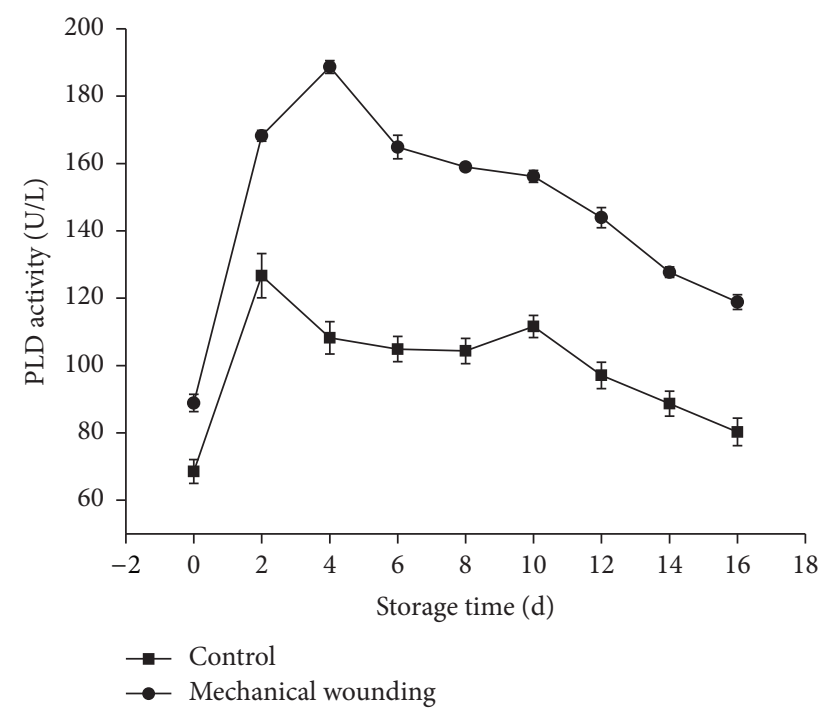

FIGURE 1: PLD activity in banana fruits dealing with mechanical wounding.

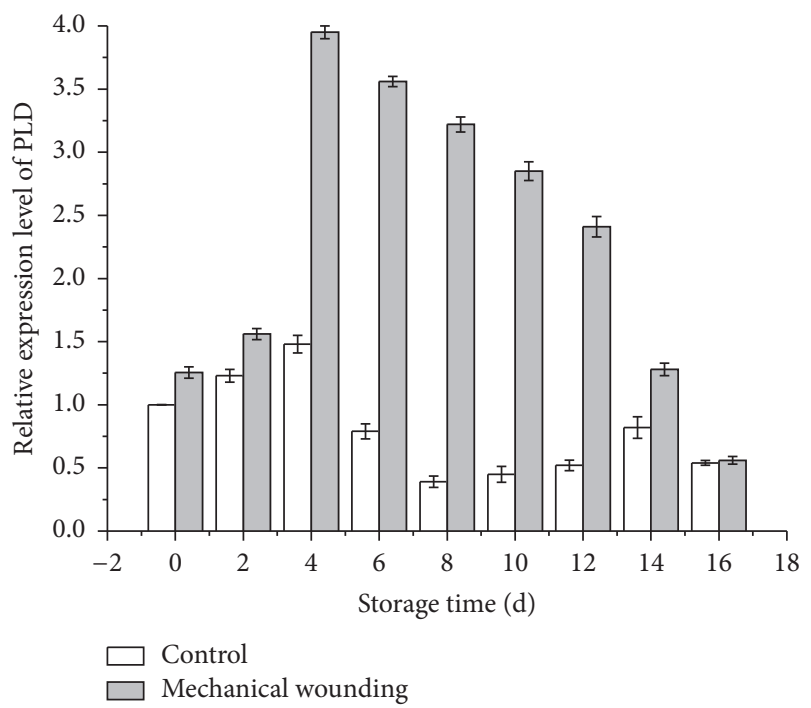

FIGURE 2: Expression analysis of MaPLD gene in banana fruits dealing with mechanical wounding.

activated by wounding. This was similar to the expression pattern found in lettuce [13]. These results suggested that PLD could be involved in producing wound signal and PLD activity in wounded fruits that were associated with the mRNA expression. PLD induced by wounding might stimulate corresponding physiological reactions related to fruit deterioration and senescence through increasing gene expression. ical Wounding. LOX is a key enzyme in phospholipid

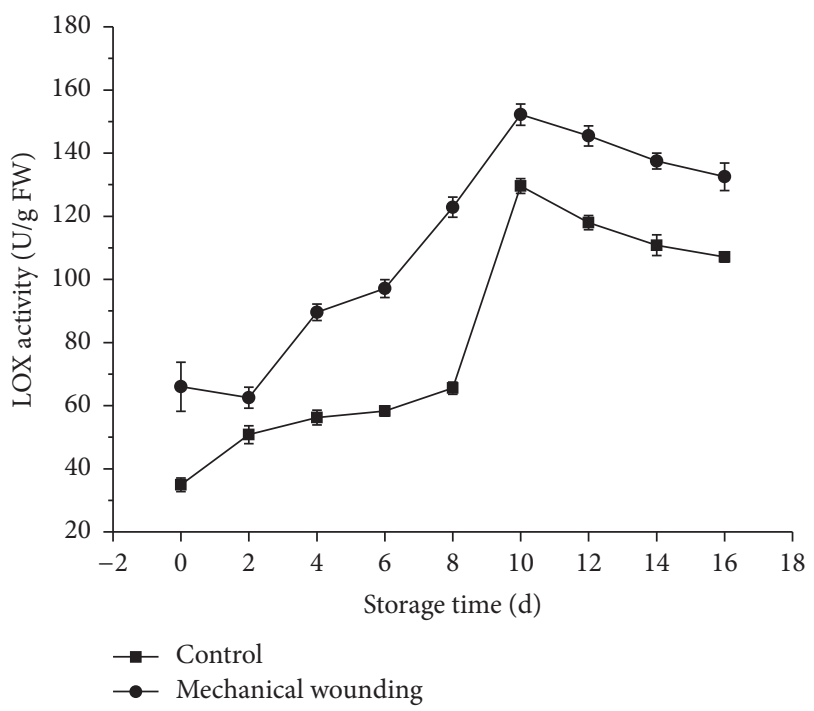

FIGURE 3: LOX activity in banana fruits dealing with mechanical wounding.

catabolism of plants, initiating a lipolytic cascade in membrane deterioration during senescence and stress. From Figure 3 , at $25^{\circ} \mathrm{C}$ and $90 \% \mathrm{RH}, \mathrm{LOX}$ activity from banana fruits increased first and then decreased during $16 \mathrm{~d}$ storage and attained maximum on day 10 in both control and wounded fruits. Much higher LOX activity was observed in wounded fruits than that in control throughout the entire storage period. Similar results were obtained by Zhao et al. who reported that LOX might be the main hydrolytic enzymes of phospholipids in response to mechanical wounding in postharvest cucumber fruits [8].

\subsection{Activities of Antioxidative Enzymes in Postharvest Banana} Fruits under Mechanical Wounding. The activities of antioxidative enzymes SOD, CAT, POD, and APX in postharvest banana fruits were shown in Figure 4. From Figure 4(a), at $25^{\circ} \mathrm{C}$ and $90 \% \mathrm{RH}$, SOD activity rose rapidly during $16 \mathrm{~d}$ storage. It was higher in wounded fruits than that in control, but there was no statistically significant difference $(P>0.05)$ on day 4. CAT activity in control showed a peak on day 14 and then declined (Figure 4(b)). However, CAT activity in wounded fruits demonstrated a rapid increasing tendency throughout the entire storage period and was significantly higher $(P<0.05)$ than that in control on days $2,4,6,8$, and 16. POD activity exhibited increasing trends in control and wounded fruits (Figure 4(c)). POD activity in wounded fruits was significantly higher $(P<0.05)$ than that in control during $16 \mathrm{~d}$ storage. APX activity was higher in wounded fruits than that in control during $16 \mathrm{~d}$ storage. This enzymatic activity presented a peak on day 12 in control. However, it still increased and significantly higher values were found in wounded fruits on days 14 and 16.

3.4. MDA Content in Postharvest Banana Fruits under Mechanical Wounding. MDA is an indicator to assess fruit 


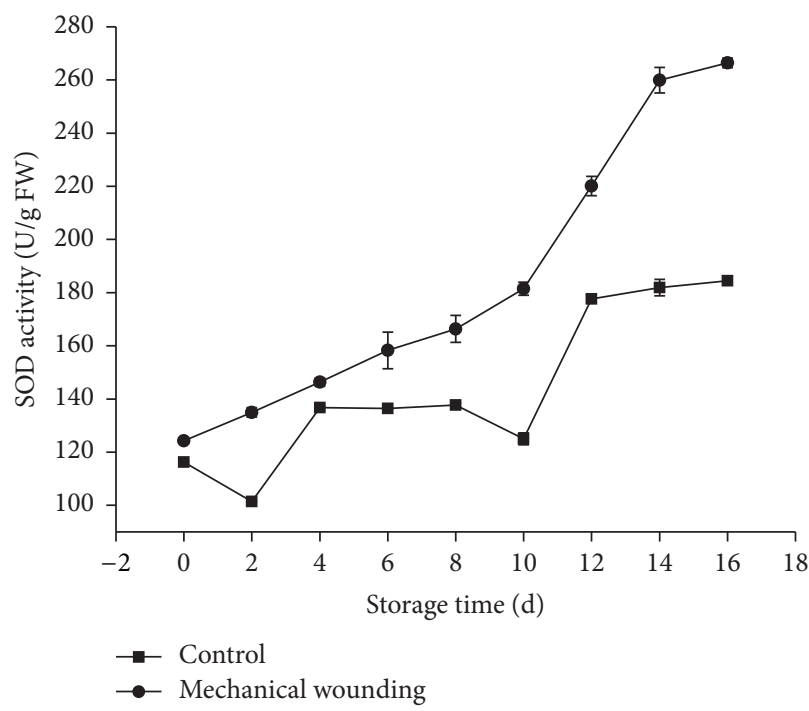

(a)

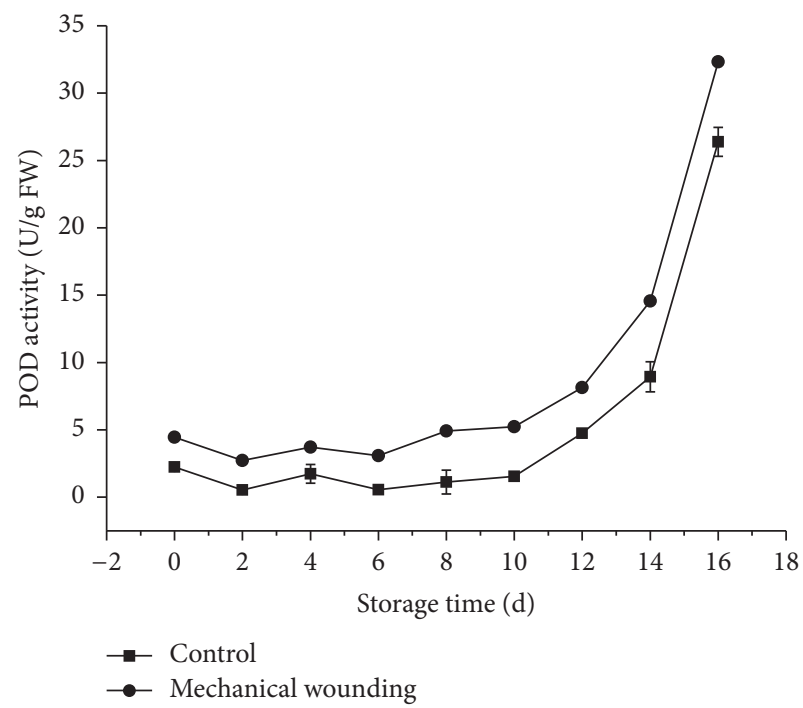

(c)

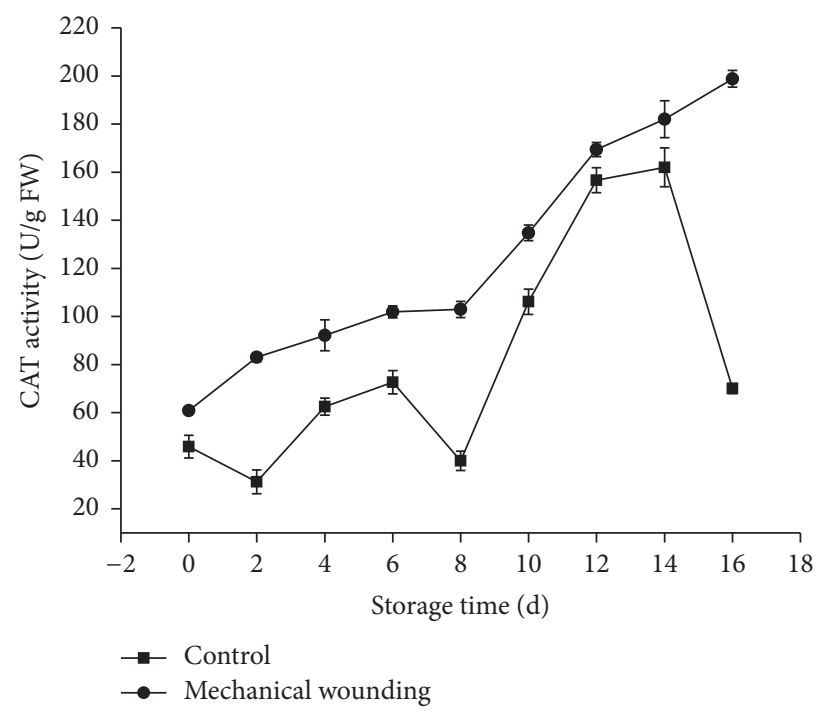

(b)

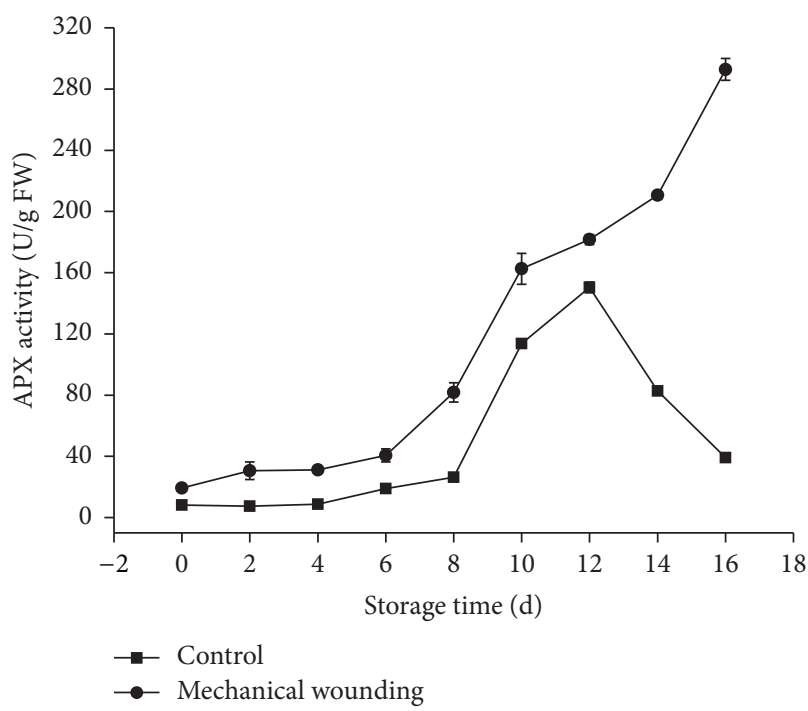

(d)

FIgURE 4: Activities of antioxidative enzymes SOD (a), CAT (b), POD (c), and APX (d) in banana fruits dealing with mechanical wounding.

damage progress, which represents the level of lipid peroxides and the structural integrity of cell membranes [26]. MDA level change is considered to be a marker for membrane lipid peroxidation of plants subjected to senescence or stress. From Figure 5, at $25^{\circ} \mathrm{C}$ and $90 \% \mathrm{RH}$, a continuous increase of MDA content was observed in both control and wounded fruits with extended storage time. MDA in wounded fruits was significantly higher $(P<0.05)$ than that in control during $16 \mathrm{~d}$ storage, indicating that mechanical wounding accelerated MDA accumulation in postharvest banana fruits.

3.5. Changes of $\mathrm{O}_{2} \cdot-$ and $\mathrm{H}_{2} \mathrm{O}_{2}$ Content in Postharvest Banana Fruits under Mechanical Wounding. Superoxide radical and $\mathrm{H}_{2} \mathrm{O}_{2}$ production in postharvest banana fruits response to mechanical wounding were investigated. Generally speaking, the contents of $\mathrm{O}_{2}{ }^{--}$and $\mathrm{H}_{2} \mathrm{O}_{2}$ in control and wounded fruits exhibited ascending first and then descending trends (Figure 6) when storing fruits for 16 days at $25^{\circ} \mathrm{C}$ and $90 \%$ $\mathrm{RH}$. From Figure 6(a), $\mathrm{O}_{2}{ }^{--}$content in wounded fruits was significantly higher $(P<0.05)$ than that in control. It reached the highest peak on day 4 in control but continually rose to maximums on day 6 in wounded fruits. $\mathrm{O}_{2}{ }^{--}$level in wounded fruits was about 5 -fold higher than that in control on day 16. From Figure 6(b), $\mathrm{H}_{2} \mathrm{O}_{2}$ content in wounded fruits showed significantly higher $(P<0.05)$ level than that in control throughout the entire storage period. It reached the highest peak on day 4 in both groups. The above results suggested that $\mathrm{H}_{2} \mathrm{O}_{2}$ could significantly increase the production rate of $\mathrm{O}_{2}{ }^{--}$in response to wounding stress. 


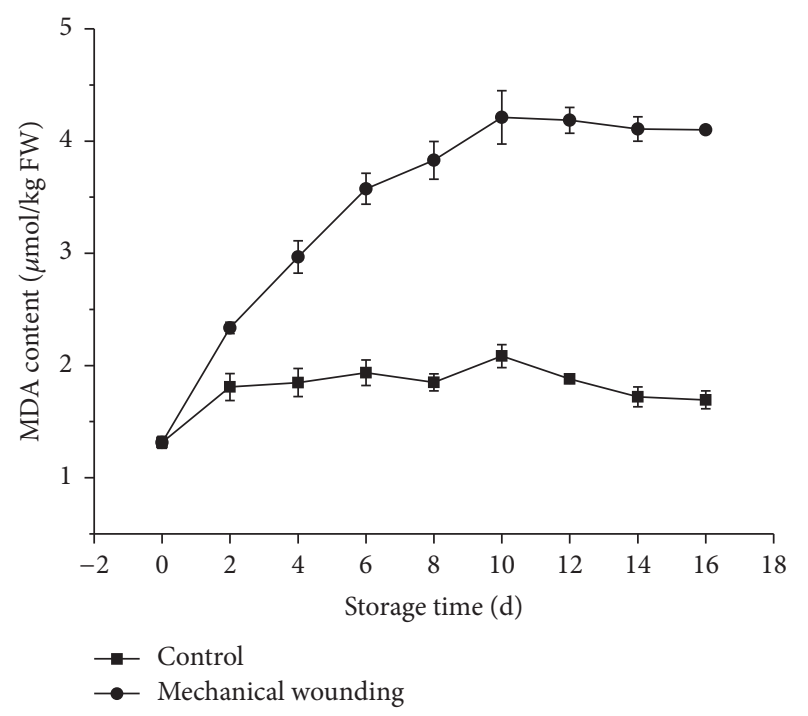

FigURE 5: MDA content in banana fruits dealing with mechanical wounding.

\section{Discussion}

Lipase and PLD are very important enzymes involved in membrane phospholipid hydrolysis [27-29]. The activities of PLD and LOX not only have impacts on cellular membrane structure and stability but also play pivotal roles in regulating many critical cellular functions, including cellular signal transduction, vesicle trafficking, cell proliferation, hormone action, cellular backbone formation, seed germination, senescence, and defense responses [9, 30]. A direct correlation was found between lipid peroxidation and phospholipid hydrolysis [3]. PLD and LOX are proposed to initiate lipolytic cascades in membrane deterioration in response to senescence and environmental stress [11]. It is proposed that PLD initiates a lipolytic cascade in membrane deterioration [27]. The resultant phospholipid degradation products could be further catalyzed by LOX to produce activated oxygen and lipid peroxides, which lead to cellular compartmentalization and membrane damage [31]. In this study, the activities of PLD and LOX in wounded banana fruits were significantly higher $(P<0.05)$ than those in control throughout the whole storage period (Figures 1 and 3 ). The higher PLD gene expression accompanying higher PLD activity was observed in wounded fruits (Figure 2), and $P L D$ gene is involved in the defense and repair process in the early damage and its effect reduced or is replaced after 4 days. Similar results were reported by Sang et al. [32], who found wounding increased the level of expression of the $P L D \alpha$ gene after stress in cucumbers. PLD and LOX induced by wounding might stimulate corresponding physiological reactions related to deterioration and senescence through increasing gene expression. Some evidences reported that the wounding-induced activation of PLD could result from PLD translocation to membrane, which is mediated by an increase in cytoplasmic calcium and stimulated by low micromolar calcium levels $[10,12]$. In addition, PLD and PA promote the production of superoxide $[33,34]$, a reactive oxygen species that is involved in various defense responses. PLD and its catalyzed products, phosphatidic acid and linolenic acid, initiate the oxylipin pathway and cellular signal transduction, which may be involved in producing the wound signal responsible for increased wound-induced activity, accumulation of phenolics, and enzymatic browning in plant tissues [6].

Membrane lipid degradation is an essential feature of signal transduction pathways that occur in response to wounding stress. Antioxidant defense systems can reduce membrane lipid peroxidation and protect plants from ROS damage. Among antioxidant systems, $\mathrm{SOD}$ can scavenge $\mathrm{O}_{2}{ }^{--}$ radicals into $\mathrm{H}_{2} \mathrm{O}_{2}$, while $\mathrm{H}_{2} \mathrm{O}_{2}$ is further converted into water by CAT and APX [15]. In this study, the increasing rate of $\mathrm{H}_{2} \mathrm{O}_{2}$ and $\mathrm{O}_{2}{ }^{--}$(major ROS) contents in wounded banana fruits exhibited ascending trend before day 4 (Figure 6), which suggested that the equilibrium between production and scavenging of $\mathrm{H}_{2} \mathrm{O}_{2}$ and $\mathrm{O}_{2}{ }^{\cdot-}$ was disturbed, and $\mathrm{H}_{2} \mathrm{O}_{2}$ and $\mathrm{O}_{2}{ }^{-}$in banana fruits were largely produced during $4 \mathrm{~d}$ storage. Lipid peroxidation product MDA resulting from ROS activity was significantly higher $(P<0.05)$ than that in control (Figure 5). Although overproduced $\mathrm{H}_{2} \mathrm{O}_{2}$ was synchronously scavenged through chain reactions catalyzed by a series of antioxidant enzymes (such as SOD, CAT, POD, and APX) (Figure 4), $\mathrm{H}_{2} \mathrm{O}_{2}$ accumulation was more than its breakdown before $4 \mathrm{~d}$ storage. After day 4 , the accumulation of $\mathrm{H}_{2} \mathrm{O}_{2}$ and $\mathrm{O}_{2}{ }^{--}$slowed down because of the enhanced scavenging effects of antioxidant enzymes (Figure 6). The results indicated that antioxidant enzymes could scavenge overproduced ROS in banana fruits, retard peroxidation of membrane lipids, inhibit the loss of membrane function, and therefore control senescence of the fruits during storage. The overproduced ROS during storage of wounded banana fruits caused lipid peroxidation, induced membrane injury, destroyed membrane integrity, and resulted in cell senescence. The equilibrium between production and scavenging of ROS in banana fruits may be disturbed by mechanical wounding during storage and thereby it incurs fruit senescence.

Considering the above analysis, the biochemical characters (i.e., membrane-associated lipolytic enzymes such as PLD and LOX, ROS, and antioxidant enzymes) are related to the wounding stress. PLD plays a role in elicitor-induced production of ROS and is involved in signaling pathways in response to wounding stresses [35, 36]. PLD associated with membrane and soluble fractions had opposite behaviors in wound response. Wounding studies performed on Arabidopsis leaves showed that PLD was differently affected by wounding and transcript changes were observed after a few hours [37]. Further study is needed to genetically and physiologically characterize different PLD in banana fruits and the signaling pathway of the PLD so as to gain a better understanding on their function under environmental stress.

\section{Conflicts of Interest}

The authors declare that they have no conflicts of interest. 


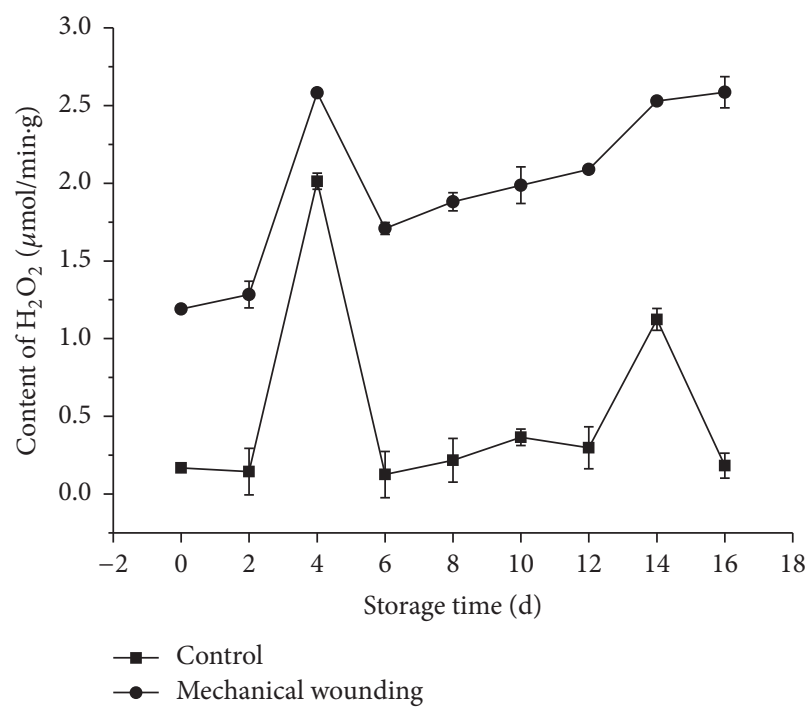

(a)

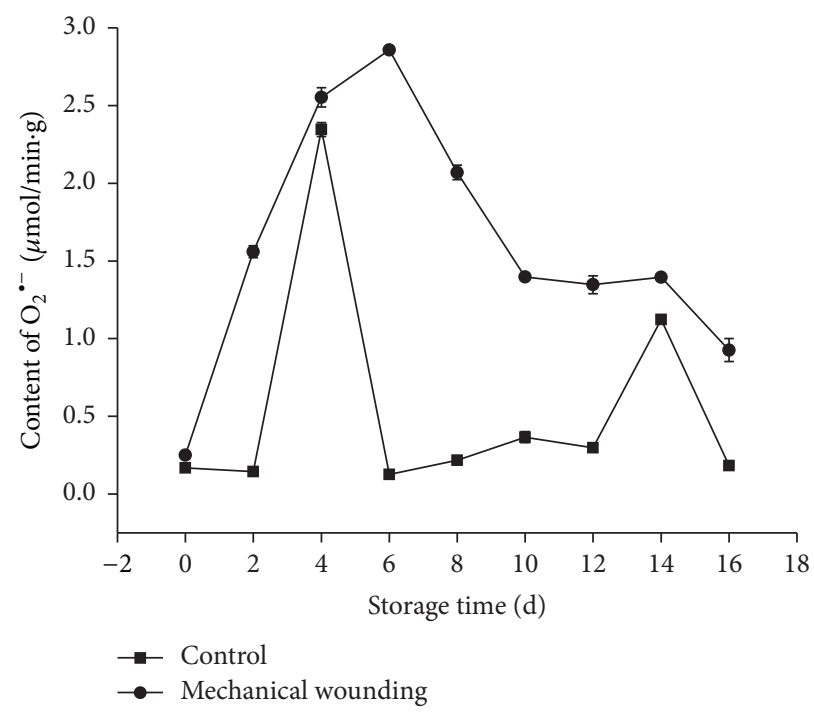

(b)

Figure 6: Changes of $\mathrm{H}_{2} \mathrm{O}_{2}$ (a) and $\mathrm{O}_{2}{ }^{--}$(b) content in banana fruits dealing with mechanical wounding.

\section{Acknowledgments}

This research was supported by the Agroscientific Research in the Public Interest (Grant no. 201303073), National Natural Science Foundation of China (Grant nos. 31160407, 31000927, 31560467, 31660589, and 31560006), Earmarked Fund for China Agriculture Research System (car-31), Bagui Scholars Project Special Fund (Grant no. [2016]21), Technology Foundation for Selected Overseas Chinese Scholar, Ministry of Personnel of China (Grant no. Ren She Ting Han [2015]192), Guangxi Natural Science Foundation (Grant nos. 2014GXNSFDA118013, 2015GXNSFBA139102), Guangxi Agricultural Key Science and Technology Program (Grant no. 201527), Guangxi Scientific Research and Technological Development Projects (Grant nos. Gui Ke AD16380015, 15104001-2), and Foundation of Fundamental Research Project from Guangxi Academy of Agricultural Sciences (Grant nos. 2015YT86, 2016JZ11, and 2017JZ10).

\section{References}

[1] M. F. B. Durigan and B.-H. Mattiuz, "Effect of mechanical injuries on the quality of watermelon stored at room temperature," Horticultura Brasileira, vol. 25, no. 2, pp. 296-300, 2007.

[2] W. J. Janisiewicz, B. Nichols, G. Bauchan, T. C. Chao, and W. M. Jurick, "Wound responses of wild apples suggest multiple resistance mechanism against blue mold decay," Postharvest Biology and Technology, vol. 117, pp. 132-140, 2016.

[3] L.-L. Song, H. Liu, Y.-L. You et al., "Quality deterioration of cut carnation flowers involves in antioxidant systems and energy status," Scientia Horticulturae, vol. 170, pp. 45-52, 2014.

[4] M. Fobel, D. V. Lynch, and J. E. Thompson, "Membrane deterioration in senescing carnation flowers: coordinated effects of phospholipid degradation and the action of membranous lipoxygenase," Plant Physiology, vol. 85, no. 1, pp. 204-211, 1987.
[5] X. Wang, "Regulatory functions of phospholipase D and phosphatidic acid in plant growth, development, and stress responses," Plant Physiology, vol. 139, no. 2, pp. 566-573, 2005.

[6] B. O. R. Bargmann and T. Munnik, "The role of phospholipase $\mathrm{D}$ in plant stress responses," Current Opinion in Plant Biology, vol. 9, no. 5, pp. 515-522, 2006.

[7] B. O. R. Bargmann, A. M. Laxalt, B. T. Riet et al., "Reassessing the role of phospholipase D in the Arabidopsis wounding response," Plant, Cell \& Environment, vol. 32, no. 7, pp. 837-850, 2009.

[8] Y. Y. Zhao, C. L. Qian, J. C. Chen, Y. Peng, and L. C. Mao, "Responses of phospholipase D and lipoxygenase to mechanical wounding in postharvest cucumber fruits," Biomed and Biotechnol, vol. 11, no. 6, pp. 443-450, 2010.

[9] X. Wang, "Multiple forms of phospholipase D in plants: the gene family, catalytic and regulatory properties, and cellular functions," Progress in Lipid Research, vol. 39, no. 2, pp. 109-149, 2000.

[10] S. B. Ryu and X. Wang, "Activation of phospholipase D and the possible mechanism of activation in wound-induced lipid hydrolysis in castor bean leaves," Biochimica et Biophysica Acta-Lipids and Lipid Metabolism, vol. 1303, no. 3, pp. 243-250, 1996.

[11] G. Paliyath and M. J. Droillard, "The mechanisms of membrane deterioration and disassembly during senescence," Plant Physiol Biochem, vol. 30, pp. 789-812, 1992.

[12] H. Yuan, L. Chen, G. Paliyath, A. Sullivan, and D. P. Murr, "Characterization of microsomal and mitochondrial phospholipase D activities and cloning of a phospholipase D alpha cDNA from strawberry fruits," Plant Physiology and Biochemistry, vol. 43, no. 6, pp. 535-547, 2005.

[13] Y.-J. Choi, F. A. Tomás-Barberán, and M. E. Saltveit, "Woundinduced phenolic accumulation and browning in lettuce (Lactuca sativa L.) leaf tissue is reduced by exposure to n-alcohols," Postharvest Biology and Technology, vol. 37, no. 1, pp. 47-55, 2005. 
[14] J. Sun, C. Li, K. Nagendra Prasad et al., "Membrane deterioration, enzymatic browning and oxidative stress in fresh fruits of three litchi cultivars during six-day storage," Scientia Horticulturae, vol. 148, pp. 97-103, 2012.

[15] K. Apel and H. Hirt, "Reactive oxygen species: metabolism, oxidative stress, and signal transduction," Annual Review of Plant Biology, vol. 55, pp. 373-399, 2004.

[16] R. Mendoza, D. A. Castellanos, J. C. García, J. C. Vargas, and A. O. Herrera, "Ethylene production, respiration and gas exchange modelling in modified atmosphere packaging for banana fruits," International Journal of Food Science \& Technology, vol. 51, no. 3, pp. 777-788, 2016.

[17] M. Hailu, T. S. Workneh, and D. Belew, "Review on postharvest technology of banana fruit," African Journal of Biotechnology, vol. 12, no. 7, pp. 635-647, 2013.

[18] G. M. Smith, R. L. Ward, L. Mcguigan, I. A. Rajkovic, and K. F. Scott, "Measurement of human phospholipase a in arthritis plasma using a newly developed sandwich elisa," Rheumatology, vol. 31, no. 3, pp. 175-178, 1992.

[19] S. B. Wan, W. Wang, P. F. Wen, J. Y. Chen, W. F. Kong, and Q. H. Pan, "Cloning of phospholipase D from grape berry and its expression under heat acclimation," BMB Reports, vol. 40, no. 4, pp. 595-603, 2007.

[20] B. Axelrod, T. M. Cheesbrough, and S. Leakso, "Lipoxygenase from soybeans," Methods Enzymol, vol. 7, pp. 443-451, 1981.

[21] K. Oracz, H. El-Maarouf-Bouteau, I. Kranner, R. Bogatek, F. Corbineau, and C. Bailly, "The mechanisms involved in seed dormancy alleviation by hydrogen cyanide unravel the role of reactive oxygen species as key factors of cellular signaling during germination," Plant Physiology, vol. 150, no. 1, pp. 494$505,2009$.

[22] J. Sun, X. You, L. Li et al., "Effects of a phospholipase D inhibitor on postharvest enzymatic browning and oxidative stress of litchi fruit," Postharvest Biology and Technology, vol. 62, no. 3, pp. 288294, 2011.

[23] Y. Nakano and K. Asada, "Hydrogen peroxide is scavenged by ascorbate- specificperoxidase in spinach chloroplasts," Plant and Cell Physiology, vol. 22, pp. 867-880, 1981.

[24] C. Dunand, M. Crèvecoeur, and C. Penel, "Distribution of superoxide and hydrogen peroxide in Arabidopsis root and their influence on root development: Possible interaction with peroxidases," New Phytologist, vol. 174, no. 2, pp. 332-341, 2007.

[25] V. Velikova, I. Yordanov, and A. Edreva, "Oxidative stress and some antioxidant systems in acid rain-treated bean plants protective role of exogenous polyamines," Journal of Plant Sciences, vol. 151, no. 1, pp. 59-66, 2000.

[26] E. Yang, W. Lu, H. Qu et al., "Altered energy status in pericarp browning of litchi fruit during storage," Pakistan Journal of Botany, vol. 41, no. 5, pp. 2271-2279, 2009.

[27] G. Paliyath and J. E. Thompson, "Calcium- and calmodulinregulated breakdown of phospholipid by microsomal membranes from bean cotyledons," Plant Physiology, vol. 83, no. 1, pp. 63-68, 1987.

[28] B. D. Whitaker, D. L. Smith, and K. C. Green, "Cloning, characterization and functional expression of a phospholipase $\mathrm{D} \alpha$ cDNA from tomato fruit," Physiologia Plantarum, vol. 112, no. 1, pp. 87-94, 2001.

[29] X. You, Y. Zhang, L. Li et al., "Cloning and molecular characterization of phospholipase D (PLD) delta gene from longan (Dimocarpus longan Lour.)," Molecular Biology Reports, vol. 41, no. 7, pp. 4351-4360, 2014.
[30] L. Li, J. Li, J. Sun et al., "Effects of 2-butanol on quality and physiological characteristics of longan fruit stored at ambient temperature," Postharvest Biology and Technology, vol. 101, pp. 96-102, 2015.

[31] G. Z. De Bruxelles and M. H. Roberts, "Signals regulating multiple responses to wounding and herbivores," Critical Reviews in Plant Sciences, vol. 20, no. 5, pp. 487-521, 2001.

[32] Y. Sang, D. Cui, and X. Wang, "Phospholipase D and phosphatidic acid-mediated generation of superoxide in Arabidopsis," Plant Physiology, vol. 126, no. 4, pp. 1449-1458, 2001.

[33] Y. Peng and L. Mao, "Salicylic acid, ethephon, and methyl jasmonate induce the expression of phospholipase $\mathrm{D}$ in mechanically-wounded cucumber," The Journal of Horticultural Science \& Biotechnology, vol. 86, no. 3, pp. 235-240, 2011.

[34] Y. Sang, S. Zheng, W. Li, B. Huang, and X. Wang, "Regulation of plant water loss by manipulating the expression of phospholipase D $\alpha$," The Plant Journal, vol. 28, no. 2, pp. 135-144, 2001.

[35] Z. Li and C. Thomas, "Quantitative evaluation of mechanical damage to fresh fruits," Trends in Food Science \& Technology, vol. 35, no. 2, pp. 138-150, 2014.

[36] L. Mao, H. Pang, G. Wang, and C. Zhu, "Phospholipase D and lipoxygenase activity of cucumber fruit in response to chilling stress," Postharvest Biology and Technology, vol. 44, no. 1, pp. 4247, 2007.

[37] X. Wang, "Phospholipase D in hormonal and stress signaling," Current Opinion in Plant Biology, vol. 5, no. 5, pp. 408-414, 2002. 

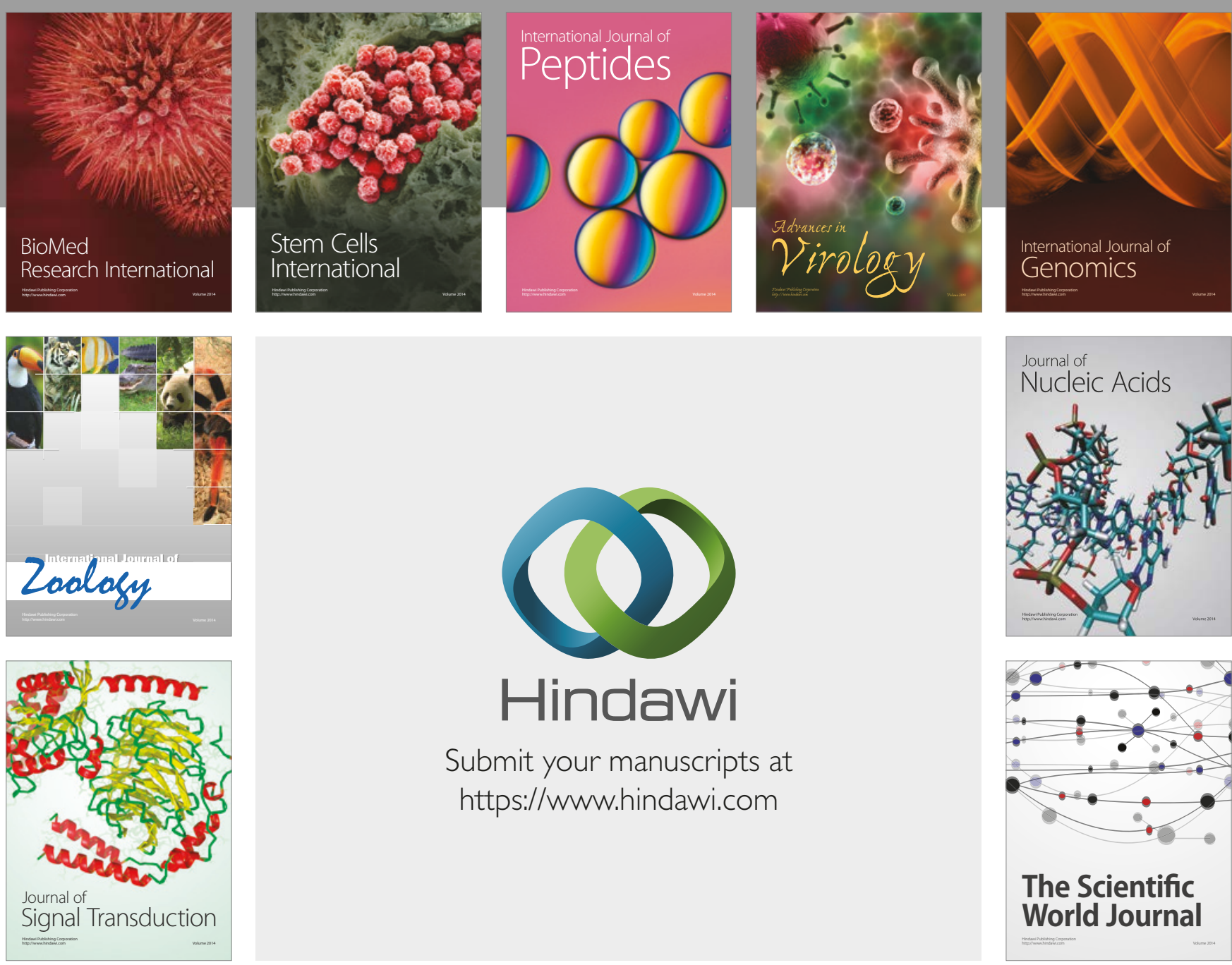

Submit your manuscripts at

https://www.hindawi.com
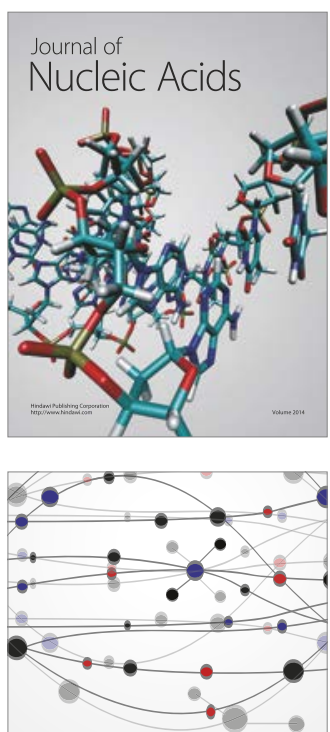

The Scientific World Journal

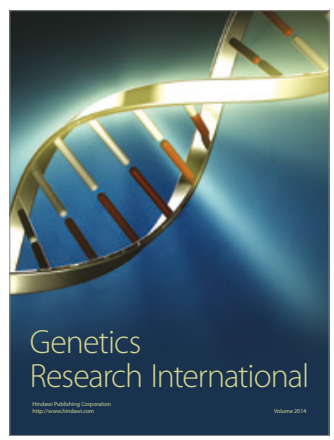

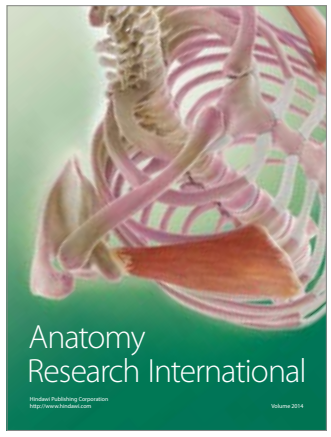

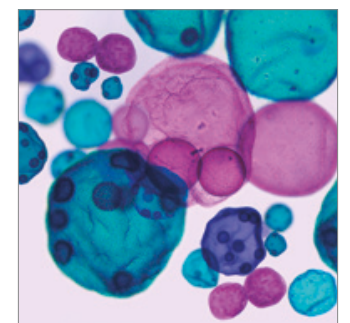

International Journal of Microbiology
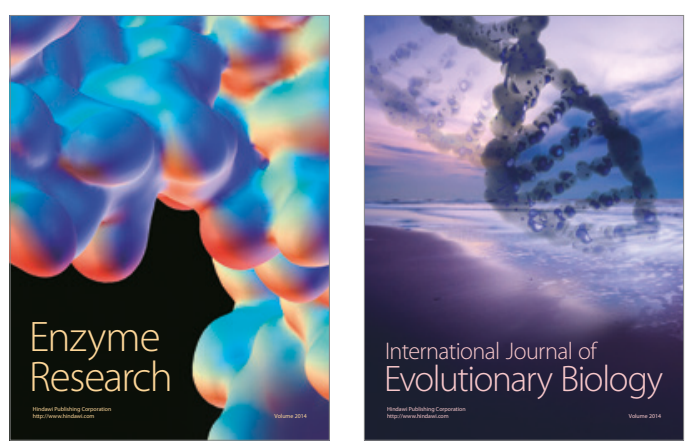
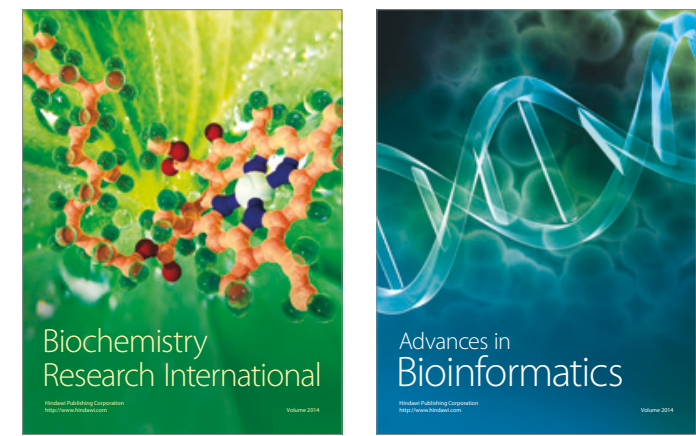

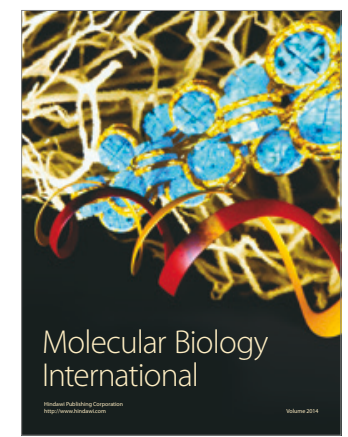

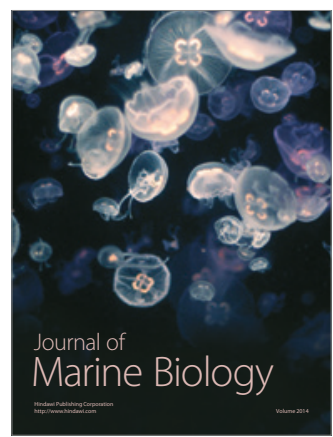

